\title{
Determinants of Tunisian Bank Efficiency: A DEA Analysis
}

\author{
Inès Ayadi ${ }^{1}$ \\ ${ }^{1}$ Faculty of Law, Economics and Management, University of Jendouba, Jendouba, Tunis \& Faculty of Economic \\ Sciences and Management of Tunis, Tunis \\ Correspondence: Inès Ayadi, Assistant at the Faculty of Law, Economics and Management, University of Jendouba, \\ Jendouba, Tunis, and PhD student at the Faculty of Economic Sciences and Management of Tunis, Tunis. E-mail: \\ ayadines@yahoo.fr
}

Received: June 12, 2013

Accepted: July 10, 2013

Online Published: October 8, 2013

doi:10.5430/ijfr.v4n4p128

URL: http://dx.doi.org/10.5430/ijfr.v4n4p128

\begin{abstract}
The objective of this research is to study the x-efficiency of Tunisian commercial banks for the period 1996-2010 using a DEA (Data Envelopment Analysis) method. Our results suggest that the cost efficiency of the sector is estimated at a score of $41.0 \%$. Market share in terms of deposit banks and their engagement in risky activities especially in the field of credit negatively affecting their efficiency. A high bank capitalization positively influences the latter. In addition, state-owned banks are more efficient than their private counterparts.
\end{abstract}

Keywords: X-efficiency, DEA (Data Envelopment Analysis), Tunisian banks

\section{Introduction}

Financial activity continues to globalize today because of deregulation. In this changing environment, the specific question of the efficiency of Tunisian banks becomes a crucial issue; the latter was affected by financial reforms being initiated in Tunisia since 1986.

In fact, this change induces increased interbank competition notably following the lifting of credit rationing and (partial) liberalization of interest rates. This situation has increased the traditional activity of banks (the collection of deposits and granting loans), which resulted in a change in the structure of banking costs and increasing size of the latter, allowing the Tunisian banks to improve their x-efficiency (the concept of $\mathrm{x}$-efficiency has been the subject of numerous studies to measure the shortfall due to poor knowledge of the technical aspects of production and misallocation of resources).

In this work, we test the differences in x-efficiency levels of Tunisian commercial banks. This helps determine the factors on which the latter may act to increase their efficiency levels and follow the demands of a more competitive environment.

Thus, the objective of our study is to assess the x-efficiency of Tunisian banks during the period 1996-2010 using DEA. We will try to answer the following question:

\section{What is the level of $x$-efficiency of Tunisian banks and what are the factors behind the latter?}

This work is divided up into three parts. The first part will discuss the major empirical studies on the determinants of bank efficiency, the second will deal with the adopted research methodology and finally, the third part presents the empirical results found along with their interpretations.

\section{The Determinants of Bank Efficiency: A Review of the Literature}

Studies that have investigated the determinants of efficiency of the banking sector are quite numerous. For example, Ferrier and Lovell (1990) who conducted a study on a sample of 575 U.S. commercial banks found that $88 \%$ of these banks are exposed to increasing returns to scale. They also establish that economies of scale do not give big banks a low cost advantage. Also, they found that allocative inefficiency mainly due to excessive use of labor and poor use of capital. The most efficient banks in the sample belong to the class of small-sized banks. This is explained by the proper application of technology, which has allowed smaller banks to overcome the disadvantages of cost of capital and to leave their products more effectively. Indeed, the evolution of technological progress has not failed to change the operation of the business of banking. 
In the Tunisian context, Chaffai (1997) is the first who is interested in studying the efficiency of Tunisian commercial banks, concluded that the efficiency of these banks has increased as a result of the process initiated in Liberal 1986.

Another study Chaffai and Dietsch (1998) in which they found that the absence of a competitive environment, the technical efficiency scores of Tunisian commercial banks deteriorated from 1989 to 1993, then they improved over the period 1994 to 2000.

According to Cook and al. (2000), there is a negative and statistically significant relationship between the size and the credit issues, and efficiency of the Tunisian banking sector estimated by the DEA method during the period 1992-1997. In addition, their results show a positive and statistically significant ownership structure on bank efficiency, in their private banks is more efficient than public banks.

Dietsch and Lozano-Vivas (2000) studied the x-efficiency of French and Spanish banks over the period 1988-1992. According to these authors, French banks (average efficiency level 88\%) are more efficient than the Spanish banks (average level of efficiency 75\%). To explain the origins of these differences, Dietsch and Lozano-Vivas (2000) have considered the effect of a set of environmental variables.

In the same methodological, vein Karray (2002) evaluated the performance of Tunisian banks in terms of productive efficiency alternatives for two periods before and after deregulation. He concluded that on average, the productive efficiency of Tunisian banks improved after deregulation.

Sathye (2003) used a DEA method to estimate the productive efficiency of banks in India, the efficiency scores for three groups of banks: public banks, private and foreign capital are measured, it showed that efficiency of commercial banks in the private sector is lower than in the public sector and foreign banks in India.

According to Girardone and al. (2004), the inefficiency scores of Italian banks over the period 1993-1996 appear inversely correlated with capital and positively related to the level of non-performing loans. This will be reflected in the fact that efficient banks pay more attention to the activities of credit monitoring. In addition, the study shows that there is no relationship between the size of assets and efficiency.

For its part, Maghyereh (2004) in a study on the efficiency of banks in Jordan said the positive response of the sector to financial liberalization with an efficiency score comparable to banks in developed countries.

Bonin and al (2005) studied the effects of ownership structure, especially the strategy of foreign ownership on efficiency of 225 banks in the countries in transition. By applying the SFA method to estimate the efficiency scores, these authors concluded that privatization is not sufficient to improve bank efficiency and public banks are less efficient than private domestic banks. These authors found that foreign-owned banks are more cost-efficient than other banks and offer better services, especially if they have a strategic foreign owner.

In the same vein, Karray and Chichti (2006) examined the efficiency of Tunisian commercial banks over the period 1999-2002. Using DEA method, they found an increasing trend of efficiency levels from one year to another. Differentiating credit institutions according to the size of their assets, they found that large banks are more efficient than small banks. Indeed, for the former, the sources of inefficiencies are allocative rather than technical; however, the inefficiencies of small banks rather explain inefficiencies of scale.

Using the SFA method for estimating the cost-efficiency scores of commercial banks in Hong Kong, the work of Kwan (2006) found that the average x-efficiency of these banks was about 16-30\%. In addition, large banks were found to be less efficient than small banks. In this context, the size effect seems to be related to differences in the characteristics of the portfolio of banks of different sizes.

Weill (2006) estimated efficiency scores using a DEA method. He showed that banks on foreign ownership have better technical efficiency than credit institutions to the domestic property.

Their share, in the world of banking as in other sectors, investment in new technology has had a positive effect on the efficiency of credit institutions. In this context, Hachana.R and Omri.A (2007) argued that investment in hardware positively affects the x-efficiency of Tunisian banks in their sample over the period 2000-2006.

Pasiouras and al. (2007) found that the capital has a significant and positive effect on the technical efficiency of Greek cooperative banks during the period 2000-2004, but it has no effect on either the allocative efficiency or on $\mathrm{x}$-efficiency of these banks. They also found a positive relationship between bank efficiency and size.

Pasiouras (2008) used a DEA method to estimate efficiency sores Greek commercial banking sector during the period 2000-2004. The results indicate that the inclusion of provisions on loans as input increases the efficiency score, but the off balance sheet items do not have a significant impact. In addition, according to this author, the banks that have 
expanded their activities abroad seem to be more technically efficient than those that run only on a national level. For Pasiouras (2008), capitalization higher credit activity and market power increase the efficiency of these banks.

Interbank competition generated by the financial reforms has led to the narrowing of interest margins and consequently cornered credit institutions to move towards non-traditional activities in order to make additional profits. In this context, for S. Belkhiria (2009) conducted a study on the impact of non-traditional activities on the performance of 10 Tunisian commercial banks measured by their cost efficiency, lending activity is not a determinant of the efficiency of these banks due to the problem of non performing loans and the size of these banks which implies stagnating economies of scale. Concerning non-traditional activities, they showed a significant and positive effect on bank efficiency.

For Rossi and al (2009), the diversification of large Austrian commercial banks over the years 1997-2003 negatively affects their cost efficiencies measured by the SFA method and positively affects their capitalization.

Using a DEA method, Sufian (2009) estimated the efficiency of the Malaysian banking sector during the Asian banking crisis in 1997; he found a significant and negative relationship between bank deposits and levels of efficiency. This implies that banks with small market shares are less efficient than banks with large market shares. On the other hand, the results show that credit institutions which have ratios of loans to total assets have higher efficiency scores. This positive relationship can be explained by the efficient market hypothesis, in fact the most efficient banks can achieve lower production costs, enabling them to offer more reasonable credit and gain market share from larger inefficient banks. In addition, the variables of ownership structure, size and profitability have a positive and significant effect on the efficiency of the Malaysian banking sector. He explained this by the fact that privately owned banks, large banks or those with high profitability are more efficient than publicly owned banks, small banks or those with low levels of profitability.

More recently, Hsiao and al (2010) studied the effect of the "first financial restructuring (FFR)" on the efficiency of 40 commercial banks in Taiwan estimated by a DEA method during the period 2000-2005. These authors find that these banks have a low efficiency in the pre-reform but this efficiency has improved during the post-reform period. For Hsing and al (2010), these results suggest that this improvement may be due to improved risk management practices and the benefits obtained from compliance with the FFR.

Staub and al (2010) studied the cost efficiency, technical efficiency and allocative efficiency of Brazilian banks during the period 2000-2007, they used a DEA method to estimate efficiency scores. The results show that these banks had low levels of $\mathrm{x}$-efficiency compared to banks in Europe and the United States. For the period with high macroeconomic volatility (2000-2002), x-inefficiency Brazilian banks can be mainly attributed to technical inefficiency rather than allocative inefficiency. They also found that public banks have more significant cost efficiencies that the foreign and private banks.

Manlagñit and Chelo (2011) examined the cost efficiency of Philippine commercial banks using the SFA method to determine the efficiency scores. The results show that the level of inefficiency is important for national banks and risk and asset quality negatively affect the efficiency of these banks. This substantial increase in cost-inefficiency could be attributed to the adverse effects of the Asian crisis of 1997, the cost of banking reform and regulatory changes that have been adopted to stabilize and strengthen the sector.

By applying a stochastic approach to a sample of 133 Chinese Commercial banks in 31 regions over the period 1999-2008, the study by Zhang and al (2012) shows that the performance of banks Measured by their efficiencies is Strongly Influenced by the effectiveness of law enforcement in the region. For them, a better legal environment, increased efficiency in the legal system and strengthening the protection of intellectual property rights are associated with a higher level of efficiency between banks.

Williams (2012) examined the relationship between bank efficiency and market power for a sample of 419 commercial banks in Latin America for the period 1985-2010. The results suggest that bank restructuring has promoted competition to the detriment of market power, and they had efficiencies under conditions of monopolistic competition.

On the other hand, Park and Weber (2006) studied the hypothesis of the Market Power (MP) theory and those of the Efficient Structure (ES) theory for a sample of Korean banks over the period 1992-2002. They found a support of the ES theory. Indeed, their results showed that efficiency had a positive effect on the performance of these banks.

Chortareas and al (2007) studied a sample of banks for a number of Latin American countries during the period 1997-2005. To do this, they tested the hypothesis of the MP theory and those of the ES theory, these authors have used DEA method to estimate x-efficiency and scale efficiency scores. Chortareas and al (2007) argue that efficiency 
improvement has increased the performance of banks in Latin America thus supporting the assumptions of the ES theory.

As for Mensi and Zouari (2011), they have tried to distinguish between the MP theory and the ES theory using DEA method to estimate x-efficiency scores and those of scale efficiency, they found support for the second theory. This result suggests that during the period 1990-2005, Tunisian banks have sufficiently adopted a competitive behavior and have improved their performance, not because of their market power, but by improving the efficiency of their operations.

\section{Empirical Study}

First we start by introducing some methodological elements necessary for the efficiency measure, and then we proceed to the presentation of the sample and data.

\subsection{Method DEA}

For the purpose of our study, we choose the DEA (Data Envelopment Analysis) to measure efficiency. We consider this approach as the most appropriate for the following reasons: First, this approach provides a higher degree of flexibility because it does not force us to choose a functional form of the border that links inputs and outputs imposed to all banks in our sample. Second, this method allows easy decomposition of technical efficiency into pure technical efficiency and scale efficiency and x-efficiency into technical efficiency and allocative efficiency when input prices are included. Third, the scores obtained with the DEA can obtain a aggregate score, which indicates the efficiency of each bank in relation to a set of compatible banks.

This method initially introduced by Charnes and al (1978) is a non-parametric approach, based on sample data; the data envelopment analysis involves using mathematical programming to construct an efficient virtual frontier. Operations on that border correspond to $100 \%$ efficient entities, while those outside this boundary are not totally efficient.

In this context, the DEA has been defined by Charnes and al (1978) as: "A mathematical programming model applied to observed data (That) provides a new way of obtaining empirical estimates of external relationships such as the production functions and /or efficiency production possibility surfaces that are the cornerstones of modern economics".

The DEA can be considered in two ways: input orientation and one output, the results differ depending on whether they adopt the assumption of constant returns to scale (CRS model: Constant Return to Scale) or returns scale variables (VRS model: Variable Return to Scale).

These two models are presented in the following paragraphs:

\subsubsection{CRS Model}

Referring to Kalaitzandonakes and al (1992), we consider a sample of $\mathrm{k}$ firms where each uses M inputs to produce different $\mathrm{N}$ outputs.

Baskets of inputs and outputs are reduced by the DEA to a pair (input, output) qualified by Charnes and al (1978): virtual input and virtual output.

For a firm in the sample, we can obtain this measure by solving the following mathematical programming model:

$$
\begin{gathered}
\operatorname{Max}_{\alpha, \beta} \alpha Y_{i} / \beta X_{i} \\
\text { S.C } \\
\alpha Y_{j} / \beta X_{j} \leq 1 \\
\text { For } \quad \mathrm{j}=1,2, \ldots . \mathrm{k}
\end{gathered}
$$

Where:

$\alpha$ et $\beta$ are the vectors of coefficients to be estimated;

Yi and $\mathrm{Xi}$ respectively vectors reviewing inputs and outputs of the firm "i".

For each firm, the program maximizes the ratio of virtual output / virtual input, forcing not to exceed 1 . Thus, firms in the sample are necessarily located on or below the efficient frontier. 
Charnes and Cooper (1962) have developed a process for fractional programming models for a formulation of the previous model in the following linear form:

$$
\begin{gathered}
\operatorname{Min} \theta \\
\text { S.C } \\
\text { Y } \lambda \geq Y_{i} \\
\theta X_{i}-X \lambda \geq 0 \\
\theta \text { any, } \lambda \geq 0
\end{gathered}
$$

Where:

$$
\begin{aligned}
\mathrm{Y} & =[\mathrm{Y} 1, \ldots \ldots \ldots, \mathrm{Yk}] \text { is a matrix } \mathrm{N} * \mathrm{k} \text { outputs. } \\
\mathrm{X} & =[\mathrm{X} 1, \ldots \ldots \ldots, \mathrm{XK}] \text { is a matrix } \mathrm{M} * \mathrm{k} \text { inputs. }
\end{aligned}
$$

$\mathrm{Yi}$ and $\mathrm{Xi}$ are respectively, the vectors of inputs and outputs of the firm "i".

$\theta$ is a scalar of arbitrary sign.

$\lambda$ is a vector of dimension $\mathrm{k}$ positive coefficients to be estimated.

The optimal solution is a measure of its technical efficiency is given by the resolution of this problem.

\subsubsection{The VRS Model}

According to Coelli and al (1998): "the CRS assumption is only appropriate when all firms are operating at an optimal scale. Imperfect competition constraints on finance etc, way cause a firm to be not operating at optimal scale".

VRS model is proposed for the first time by Banker and al (1984), this model is an extension of the CRS model but takes into account situations where returns to scale are not constant. In this case, the CRS model can be modified taking into account the hypothesis of variable returns to scale. Simply add a constraint on the parameters of intensity CRS model, we obtain:

$$
\begin{gathered}
\operatorname{Min} \theta \\
\text { S.C } \\
\text { Y } \lambda \geq Y_{i} \\
\theta X_{i}-X \lambda \geq 0 \\
\theta \text { any, } \lambda \geq 0 \\
\text { N1' } \lambda=1
\end{gathered}
$$

Where:

$\mathrm{N} 1$ is a $\mathrm{N}^{*} 1$ vector of units.

To Coelli and al (1998), a good measure of scale efficiency of a firm is the difference between the index of technical efficiency obtained through DEA type CRS and the obtained by the DEA type VRS. On the same database to get such a measure, these researchers suggest performing a DEA, CRS type and another VRS type. If there is a difference for a given firm in the efficiency index measured by these two types of DEA, this implies that the firm does not operate at an optimal scale. The scale inefficiency is the result of the difference between CRS technical inefficiency and VRS technical inefficiency.

In this work, we use the DEA input-oriented variable returns to scale. First, the input-oriented method allows us to determine the cost savings of input possible to achieve for each unit of the sample if it was as efficient as the firm best practices. Second, this method can test the hypothesis of scale variable returns that is most consistent with the environment of imperfect competition in which credit institutions operating in Tunisia, in fact, the hypothesis scale constant returns is only appropriate if the firm operates at an optimal scale, which is not always the case. 


\subsection{Application}

The period of this study covers the years range between 1996-2010; the data used are taken from the annual reports of the APTBEF (Association Professionnelle Tunisienne des Banques et des Etablissements Financiers).

\subsubsection{Presentation of the Sample}

The selection of banks is exclusively on Tunisian commercial banks for two reasons. On the one hand, they play the most important role in financing the economy, and secondly, to avoid difficulties due to lack of data.

The sample consists of 10 commercial banks which are as follows:

STB: Sociétés Tunisiennes de Banques

BNA: Banque Nationale Agricole

BIAT: Banque International Arabe de Tunisie

BH: Banque de l'Habitat

AB: Amen Bank

BAT: Banque Attijari de Tunisie

UIB: Union Internationale de Banques

BT: Banque de Tunisie

ATB: Arab Tunisian Bank

UBCI: Union Bancaire pour le Commerce et l'Industrie

\subsubsection{Definition of Data}

Before defining the data, we choose the approach as related to banking production. And considering the operation of the Tunisian banking system where banks use deposits collected to be involved in a credit policy, it seemed more logical to adopt the approach of mediation. This approach assumes that the bank collects deposits to transform them into loans including labor and capital in the process of transformation, as opposed to the production approach which assumes that the bank uses labor and capital to produce deposits and loans.

Thus, according to the intermediation approach, inputs, their costs, prices and outputs are shown in the following table:

Table 1. Inputs, their costs, prices and outputs

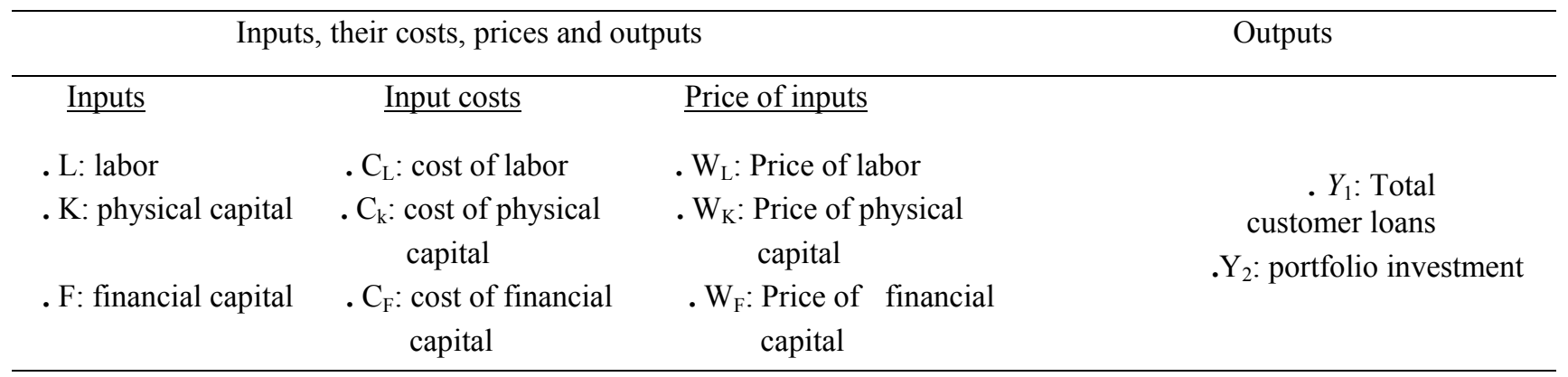

\section{Inputs:}

- $\mathrm{L}=$ number of bank employees.

- $\mathrm{K}=$ net fixed assets.

- $\mathrm{F}=$ total bank deposit.

\section{Input costs:}

- CL: payroll.

- CK: capitalized value + depreciation and provisions.

- CF: expenses incurred on foreign cash and deposits on customer loads + expense on bonds + miscellaneous losses.

\section{Price of inputs:}

$-\mathrm{WL}=\mathrm{CL} / \mathrm{L}$

$-\mathrm{WK}=\mathrm{CK} / \mathrm{K}$ 
$-\mathrm{WF}=\mathrm{CF} / \mathrm{F}$

outputs:

- Y1 = wallet discount receivable + customer loans on special resources + other loans to customers.

- Y2 $=$ is a line item in the balance sheet.

\section{Empirical Results and Interpretations}

We will focus, first of all the scores of x-efficiency of Tunisian banks in our sample, then the explanatory factors of the latter.

\subsection{Efficiency of Tunisian Banks}

The mean values of $\mathrm{x}$-efficiency scores are outlined in the following table:

Table 2. X-efficiency scores during the period 1996-2010

\begin{tabular}{lc}
\hline Banks & X-efficiency \\
\hline STB & 0,610 \\
BNA & 0,414 \\
BIAT & 0,551 \\
BH & 0,286 \\
AB & 0,299 \\
BAT & 0,375 \\
UIB & 0,420 \\
BT & 0,439 \\
ATB & 0,296 \\
UBCI & 0,401 \\
Medium & 0,410 \\
\hline
\end{tabular}

From this table, we see that the average X-efficiency has evolved mixed between 1996 and 2010 . So the efficiency of Tunisian commercial banks is fluctuating.

X-efficiency of the sector during the period 1996-2010 is estimated at an average score of $41.0 \%$. This is reflected by the fact that inefficiency cost is on average around $59.0 \%$. In other words, the inefficiency term reflects a waste of resources in the Tunisian banking sector of around $59.0 \%$.

More personalized results, we can see a better x-efficiency for public banks (STB, BNA and BH) with a score of 43 , 6\%. Private banks (BIAT, AB, UBCI, BT, ATB, BAT and UIB) show a lower score, it is about 39, 7\%. In this context, the differences between the levels of efficiency of public banks and private banks provisioning differences between the modes of creation and management of the assets of each type of bank. It follows that the public banks have better control costs because they can better control their spending and better supervise their activities. Indeed, they are able to improve their level of efficiency because they are motivated by maximizing their profit in order to meet the needs of shareholders and thereafter they are opting for further diversification of activities.

\subsection{Factors Explaining Efficiency of Tunisian Banks}

In this research, we selected some variables that seem to explain better x-efficiency of Tunisian banks. Estimating function is:

$$
X E F F_{i, t}=\alpha+\beta_{1} C O N C_{t}+\beta_{2} M S_{i, t}+\beta_{3} L A_{i, t}+\beta_{4} K A_{i, t}+\beta_{5} O W N_{i, t}+\beta_{6} \log T A_{i, t}+\varepsilon_{i, t}
$$

With:

- $\boldsymbol{C O N C}_{t}$ : the variable reflecting market concentration for the year $\mathrm{t}$, we use the HHI Herfindahl-Hirschman to measure this variable. The Herfi.ndahl-Hirshman index uses market share as the main variable. It is defined as the sum of the squares of the share of each bank in the market.

We generally believe that highly concentrated banking sector promotes less competition and risk of damaging the efficiency of banks. Thus, a negative coefficient for this variable is expected.

- $\boldsymbol{M} \boldsymbol{S}_{\boldsymbol{i}, \boldsymbol{t}^{*}}$ is the market share in terms of deposit of bank $\mathrm{i}$ in the year $\mathrm{t}$. It is the ratio of total bank deposit of each in relation to the sum total of all deposit banks in the sample. 
A high ratio of MS notes that banks with larger market shares would be the most efficient. Thus, a positive sign for the coefficient of this variable is expected.

- $\boldsymbol{L} \boldsymbol{A}_{\boldsymbol{i}, \boldsymbol{t}}:$ a variable that reflects the quality of the assets of bank i in year t. It is measured by the ratio of credit / total assets.

A high ratio of LA is associated with significant profits as it reflects superior performance of bank assets whose funds are the most risky for their growth tends to increase the efficiency of credit institutions. Thus we expect the coefficient on this variable to be positive.

- $\boldsymbol{K} \boldsymbol{A}_{i, t}:$ a variable that refers to the degree of capitalization of the bank i in year $\mathrm{t}$, it is the ratio of equity / total assets.

A high ratio of KA is an indicator of a high bank capitalization that can positively affect bank efficiency. As a positive sign of the coefficient of this variable is expected.

- $\boldsymbol{O W N} \boldsymbol{W N}_{i, t}$ : dummy variable for the ownership structure of the bank i in year t. It takes the value 0 for state banks and the value 1 for private banks.

Several theoretical and empirical studies have shown that private banks and privatized institutions are considered more efficient than public banks because of their greater capacity to reduce costs. Thus, a positive sign for the coefficient of this variable is expected.

- $\log T A_{i, t}$ : This variable refers to the size of the bank $\mathrm{i}$ in the year $\mathrm{t}$ measured by the logarithm of total assets. It is included in the model to account for differences in bank efficiency caused by the size effect. More specifically, it is used to confirm if it is related to economies or diseconomies of scale. Thus the coefficient of logTA can show a positive (presence of economies of scale) or a negative (presence of diseconomies of scale). Thus, the expected sign is ambiguous.

\subsubsection{Empirical Results}

Table 3. Descriptive statistics of variables

\begin{tabular}{lcccc}
\hline Variables & Max & Min & Mean & Std. Dev \\
\hline xeff & 1 & 082 & 40952 & 2318513 \\
conc & 1392584 & 1007152 & 1208441 & 0138075 \\
ms & 2053008 & 0051407 & 0999038 & 0406156 \\
la & 9196292 & 030293 & 7528885 & 1161702 \\
ka & 1748179 & 0329519 & 0932926 & 0289255 \\
own & 1 & 0 & 5866667 & 4940813 \\
logta & 21.72574 & 13.52569 & 14.87252 & 1.482113 \\
\hline
\end{tabular}

Table 4. Correlation matrix between the variables

\begin{tabular}{lcclcccc}
\hline & xeff & conc & $\mathrm{ms}$ & la & $\mathrm{ka}$ & own & logta \\
\hline Xeff & 1.0000 & & & & & & \\
conc & 0.0131 & 1.0000 & & & & & \\
ms & -0.2146 & 0.0020 & 1.0000 & & & & \\
la & -0.0072 & 0.4610 & -0.1114 & 1.0000 & & & \\
Ka & 0.1728 & -0.0957 & -0.3458 & 0.1777 & 1.0000 & & \\
logta & -0.1137 & 0.1718 & -0.4902 & -0.0809 & 0.1693 & 1.0000 & \\
own & -0.1402 & 0.0720 & 0.2632 & 0.1017 & -0.1743 & -0.2252 & 1.0000 \\
\hline
\end{tabular}

For the estimated model, Table 4 shows that the correlation matrix is to verify the degree of correlation between variables, revealing that the level of correlation between them is very small which justifies the absence of multi collinearity. 
Table 5. Hausman tests

\begin{tabular}{lcc}
\hline & Hausman test statistic & Fixed effect \\
\hline Model & 0,9988 & random effect
\end{tabular}

As the data are panel data, we have to specify the fixed effects estimation or random effects. Therefore, the Hausman specification test for the model is required. From Table, the probability of chi $2=0.9988>5 \%$, so the estimate for this model is the random effects.

Table 6. Results of estimating the random effects

\begin{tabular}{lllll}
\hline Xeff & Coef & Std. Err & $\mathrm{Z}$ & $\mathrm{P}>|\mathrm{z}|$ \\
\hline conc & 9165413 & 2.214664 & 0.41 & 0.679 \\
$\mathrm{~ms}$ & -9383006 & 5517803 & -1.70 & $0.089^{*}$ \\
$\mathrm{la}$ & -0911992 & 0371834 & -2.45 & $0.004^{* * *}$ \\
$\mathrm{ka}$ & 1.03085 & 2959770 & 3.48 & $0.000^{* * *}$ \\
own & -0071427 & 0017069 & -4.16 & $0.000^{* * *}$ \\
logta & -0113093 & 0132799 & -0.85 & 0.394 \\
cons & 5373818 & 3264969 & 1.65 & 0.100 \\
R-sq: within & $=0.0783$ & & & \\
Between & $=0.0022$ & & & \\
Number of obs & $=150$ & & & \\
Number of groups & $=10$ & & & \\
\hline
\end{tabular}

* A significant at $10 \%$.

*** A significant at $1 \%$.

\subsubsection{Interpretations}

From Table 6, the coefficient of the variable CONC is not significant; this implies that the concentration of Tunisian commercial banks in our sample did not influence their efficiency.

Regarding the MS variable, its coefficient is significant and displays an unexpected negative sign; this suggests that the market share in terms of filing of Tunisian commercial banks in our sample negatively influences their efficiencies.

The regression results show that the coefficient of the variable LA is significant and displays an unexpected negative sign. This suggests that most banks in our sample engage in risky activities including credit, plus they are less efficient.

Indeed, a high ratio of LA negatively affects the efficiency of Tunisian banks because it reflects a lower yield of bank assets. In other words, the predominance of credit activity is a source of a decrease in the efficiency of these credit institutions.

In this context, with little concern for the quality of their assets and risk, these banks are less efficient because they suffer from under-evaluation of credit risk and a misallocation of resources. Thus, the cost of these banks increases with non-performing loans and have implemented insufficient provisioning to cover problem loans.

As for the case of KA variable, the results show a significant coefficient with the expected positive sign. This contribution expected sign is justified by the fact that increasing the degree of capitalization of banks in our sample results in greater efficiency. This result allows us to say that a well-capitalized bank faces future bankruptcy costs low, which reduces its cost of capital. Thus, a high bank capitalization can positively affect the efficiency of the bank providing healthy banking system and reducing risk-taking incentives in credit decisions.

The table shows that the dummy variable for ownership structure OWN displays an unexpected sign, it is significant and negatively correlated with x-efficiency of banks in our sample. Therefore, public banks are more efficient than their private's counterparts. This can be explained by the fact that x-efficiency of these banks is favored by the shareholding by public institutions, most of which have trained staff and are able to evolve in a liberal economy with major management capacity.

In addition, we can say that in a developing country as Tunisia, the state plays the crucial role in the economic life and the private sector alone is unable to ensure the proper functioning of the economy. 
The results shown in Table (6) show that the size of the bank approximated by the variable log TA is not significant; this suggests that the advantage of the efficiency of Tunisian commercial banks in our sample is not influenced by the size.

It should be noted that Tunisia is living a historic moment, indeed the year 2011 has been marked by the January 14 Revolution in Tunisia and its impact on the Tunisian banking sector, its weakness and immobility have become a major concern. In this context, too undercapitalized, banks no longer play their engine role in the economy. Indeed, because of insufficient capital, they are unable to increase their loan volumes and then they are unable to improve their efficiencies.

It is imperative that Tunisian banks make further efforts to increase their capital. For this, the head of government Hamadi Jebali said on January 23 that the World Bank has provided a grant of 500,000 dollars to Tunisia and will budget support in 2013.

\section{Conclusions}

Empirical results are very satisfactory and lead to the following conclusions:

- The x-efficiency of Tunisian commercial banks during the period 1996-2010 is estimated at an average score of $41.0 \%$. This could mean that the inefficiency term reflects a waste of resources in the Tunisian banking sector of around $59.0 \%$.

- The concentration of Tunisian commercial banks in our sample did not influence their efficiency.

- The market share in terms of filing of Tunisian commercial banks negatively affects their efficiency.

- More banks in our sample engage in risky activities including credit, plus they are less efficient. In other words, the predominance of credit activity is a source of a decrease in the efficiency of these credit institutions.

- An increase in the degree of capitalization of Tunisian commercial banks in our sample results in greater efficiency.

- Public banks are more efficient than their private's counterparts.

- The advantage of the efficiency of Tunisian commercial banks is not influenced by the size.

In addition, bank efficiency can be positively affected by investment in non-traditional activities. These activities can improve the latter because they do not cause a lot of expenses for banks, unlike traditional intermediation activities that require huge expenditures such as the establishment of new agencies, as well as investment in new technologies to change the methods by which customers have access to banking products and services.

In this context, changes undergone by Tunisian banks have resulted in the option of diversifying their activities. Indeed, we are witnessing reconciliation operations between financial institutions, such as the merger between banks and insurance companies giving birth to "bancassurance".

Thus, it should be noted that there are other avenues of research that can be explored. Indeed, it would be very interesting to study the impact of the sale of insurance products on the efficiency of Tunisian banks: Bank-insurance.

\section{References}

Banker, R., Charnes, A., \& Cooper, W. (1984). Some Models for Estimating Technical and Scale Inefficiency in Data Envelopment Analysis. Management Science, 30, 1078 -1092. http://dx.doi.org/10.1287/mnsc.30.9.1078

Belkhiria, S. (2009). Impact des activités bancaires non traditionnelles sur l'efficience des banques tunisiennes: Approche de la frontière stochastique, Soumission pour les ateliers Workshop AFFI 2009.

Bonin, J.P., Hasan, I., \& Wachtel, P. (2005a). Bank performance, efficiency and ownership in transition countries. Journal of Banking and Finance, 29, 31-53. http://dx.doi.org/10.1016/j.jbankfin.2004.06.015

Chaffai, M.E. (1997). Estimation des frontières d'efficience: un survol des développements récents de la littérature. Revue d'Economie de Développement, 3,33-67.

Chaffai, M.E., \& Dietsch, M. (1998). Productive efficiency performances of Tunisian and Moroccan banks: an econometric analysis using panel data. Paper presented at the ERF Fourth annual conference, Beirut 7-9 September.

Charnes, A., \& Cooper, W. (1962). Programming with Linear Fractional Functionals. Naval Research Logistics Quarterly, 9, 181-185. http://dx.doi.org/10.1002/nav.3800090303 
Charnes, A., Cooper, W., \& Rhodes, E. (1978). Measuring the efficiency of decision-making units. European Journal of Operational Research, 2, 429-444. http://dx.doi.org/10.1016/0377-2217(78)90138-8

Chortareas, G., Garcia, J.G., \& Girardone, C. (2007). Performance-Structure and market power versus efficiency in Latin American Banking. Working Papers, Presented in conference.

Coelli, T., D.S. Prasada, Rao, \& G.E. Battese. (1998). An Introduction to Efficiency and Productivity Analysis. Kluwer Academic Publishers, Boston. http://dx.doi.org/10.1007/978-1-4615-5493-6

Cook, W.D., Habadou, M., \& Roberts, G. (2000). Financial liberalization and efficiency in Tunisian banking industry: DEA tests. Schulich School of business, York University, September 2000.

Dietsch, M., \& Lozano, Vivas A. (2000). How the environment determines banking efficiency: A comparison between French and Spanish industries. Journal of banking and finance, 24, 985-1004. http://dx.doi.org/10.1016/S0378-4266(99)00115-6

Ferrier, G.D., \& Lovell, C.A.K (1990). Measuring cost efficiency in banking: Econometric and linear programming evidence. Journal of Econometrics, 46(1-2), 229-245. http://dx.doi.org/10.1016/0304-4076(90)90057-Z

Girardone, C., Molyneux, P., \& Gardener, Edward, P.M., (2004). Analyzing the Determinants of Bank Efficiency: The Case of Italian Banks. Applied Economics, 36, 215-227. http://dx.doi.org/10.1080/0003684042000175334

Hachana, R., \& Omri, A. (2007). L’investissement en Technologies de l'Information et productivité des banques tunisiennes. Article Tagué, marrakech.

Hsiao, H. C. Chang, H. Cianci, A. M., \& Huang, L. H, (2010). First financial restructuring and operating efficiency: evidence from Taiwanese commercial banks. Journal of Banking and Finance. 34, 1461-1471. http://dx.doi.org/10.1016/j.jbankfin.2010.01.013

Kalaitzadonakes, N.G., Wu, S., \& Ma, J.C. (1992). The relationship between technical efficiency and firm size revisited. Canadian Journal of Agricultural Economics, 40, 427-442. http://dx.doi.org/10.1111/j.1744-7976.1992.tb03705.x

Karry, C.S. (2002). Taille et efficience productive des banques: Application de l'approche DEA a un échantillon de banques commerciales tunisiennes, L'entreprise tunisienne à l'heure de la libéralisation. Publication des travaux de recherches du colloque de Mai 2001.

Karray, C., \& Chichti, J. (2006). Efficience, productivité et progrès technologique en fonction de la taille de la firme bancaire : preuves empiriques sur les banques commerciales en Tunisie. Euro-mediterranean Economics and Finance Review, 1(2).

Kwan, S. H. (2006). The X-efficiency of commercial banks in Hong Kong. Journal of Banking and Finance, 30(4), 1127-1147. http://dx.doi.org/10.1016/j.jbankfin.2005.05.016

Maghyereh, A. (2004). The Effect of Financial Liberalization on the Efficiency of Financial Institutions: The Case of Jordanian Commercial Banks. Journal of Transitional Management Development, 9(2/3), 71-106. http://dx.doi.org/10.1300/J130v09n02_05

Manlagñit, Maria Chelo V. (2011). Cost Efficiency, Determinants and Risk Preferences in Banking: A Case of Stochastic Frontier Analysis in the Philippines. Journal of Asian Economics, (Elsevier Inc.), 23-35.

Mensi, S., \& Zouari, A. (2011). Banking Industry, Market Structure and Efficiency: The Revisited Model to Intermediary Hypotheses. International Journal of Economics and Research, 2(1), 23-36.

News Nationales, 2013.

Park Kang H., \& William L. Weber. (2006). Profitability of Korean banks: Test of market structure efficient structure. Journal of Economics and Business, 58, 222-239.

Pasiouras, F. (2008). Estimating the technical and scale efficiency of Greek commercial banks: The impact of credit risk, off-balance sheet activities, and international operations. Research in International Business and Finance, 22(3), 301-318. http://dx.doi.org/10.1016/j.ribaf.2007.09.002

Pasiouras, F., Sifodaskalakis, E., \& Zopounidis, C. (2007). Estimating and analysing the cost efficiency of Greek cooperative banks: An application of two-stage data. Managerial Auditing Journal, 22(3).

Rossi, M. Schwaiger, \& Winkler, G. (2009). How loan portfolio diversification affects risk, efficiency and capitalization: A managerial behavior model for Austrian banks. Journal of Banking and Finance, 33, $2218-2226$. 
http://dx.doi.org/10.1016/j.jbankfin.2009.05.022

Sathye, M. (2003). Efficiency of Banks in a Developing Economy: The Case of India. European Journal of Operational Research, 148(3), 662-671. http://dx.doi.org/10.1016/S0377-2217(02)00471-X

Staub, R. B., Souza, G., \& Tabak, B.M. (2010). Evolution of bank efficiency in Brazil: a DEA approach. European Journal of Operational Research, 202, 204-213. http://dx.doi.org/10.1016/j.ejor.2009.04.025

Sufian, F. (2009). Determinants of bank efficiency during unstable macroeconomic environment: Empirical evidence from Malaysia. Research in International Business and Finance, 23(1), 54-77. http://dx.doi.org/10.1016/j.ribaf.2008.07.002

Weill, L. (2006). Propriété étrangère et efficience technique des banques dans les pays en transition : Une analyse par la méthode DEA. Revue Economique, 57(5), Septembre, 1093-1108. http://dx.doi.org/10.3917/reco.575.1093

Williams, J. (2012). Efficiency and market power in Latin American banking. Journal of Financial Stability, 8(4), 263-276. http://dx.doi.org/10.1016/j.jfs.2012.05.001

Zhang, J.H, Wang, P., \& Qu, B.Z. (2012). Bank risk taking, efficiency, and law enforcement: Evidence from Chinese city commercial banks. China Economic Review, 23(2), 284-295. http://dx.doi.org/10.1016/j.chieco.2011.12.001 